\title{
INFORMATION FLOWS IN THE PROCESSES OF SOCIAL AND POLITICAL CHANGES IN CONSIDERATIONS OF PHILOSOPHERS \& THINKERS THROUGHOUT HISTORY
}

PRZEPŁYWY INFORMACJI W PROCESACH SPOŁECZNO-POLITYCZNYCH ZMIAN W ROZWAŻANIACH FILOZOFÓW I SOCJOLOGÓW NA PRZESTRZENI DZIEJÓW

\begin{abstract}
Purpose: The goal of this paper is to discuss and analyze works of selected philosophers and scholars from the perspective of information flows.

Method: To achieve the goal the author has chosen a few philosophers and scholars, whose works touched upon the problems of information flows and relations between actors in various types of entities (e.g. army, society, state, bureaucracy, person). The author highlighted most important elements in these works and how they relate to the problem of information flows.

Results: It is evident that even ancient philosophers discussed information flows when thinking about various change and transformation processes. it is also clear that tools and techniques used to explore information flows, change and transformation evolved over time.

Discussion: This paper is an analysis of select philosophers and scholars from the perspective of modern concepts such as information flows, change and transformation. Based on this introductory analysis the conclusion is that some interesting and forgotten knowledge can be discovered, which is worth further exploration in future research.
\end{abstract}




\section{STRESZCZENIE}

Cel: Celem niniejszego artykułu jest analiza rozważań filozofów i myślicieli (na przestrzeni dziejów) na temat przepływów informacji w procesach zmiany i transformacji.

Metody: Do analizy został wykorzystany dorobek myślicieli tworzących w różnych epokach i dziedzinach. Autor wybrał kluczowe prace i na ich podstawie pokazał stosunek twórcy do procesów informacyjnych (a w szczególności ich przepływów) w kontekście zmiany i transformacji.

Wyniki: Można zauważyć, że już od starożytności myśliciele rozpatrywali przepływy informacji w kontekście zmiany i transformacji. Ten trend ulegał stopniowej systematyzacji i ustrukturyzowaniu, by w czasach nowożytnych zakorzenić się $\mathrm{w}$ wielu dziedzinach nauki (psychologia, socjologia, zarządzanie).

Omówienie: Niniejszy artykuł jest ciekawym retrospektywnym spojrzeniem na rozważania filozofów naszej cywilizacji z perspektywy elementu, który na co dzień jest obecny w wielu dziedzinach nauki i życia - przepływu informacji i zmiany. Patrząc w przeszłość, możemy dostrzec elementy wiedzy dawno odkrytej, ale obecnie zapomnianej. Taka refleksja nad istotnym elementem naszego obecnego życia może być inspiracją do kolejnych badań i rozważań w wielu dziedzinach.

KEYWORDS: information flows, change, philosophy, thinker, socjology, society

SŁoWA KLUCzowE: przepływy informacji, zmiana, filozofia, myśliciel, socjologia, spoteczeństwo

\section{WPROWADZENIE}

Przepływy informacji w obecnym świecie są istotnym elementem zarówno w wielu obszarach nauki, jak i codziennego życia. Sama informacja jest bardzo szerokim pojęciem. Dobrze to oddaje poniższy cytat: „Informacja, nie będąc konkretną rzeczą, nie przyjmuje jednolitej postaci, nie ma też jednorodnego podłoża; można ją rozpoznać w wielu rzeczach. Ma naturę zdarzenia relacyjnego. Mówiąc abstrakcyjnie, przyjmuje formę możliwości reagującej w konkretnych sytuacjach. W działaniu układów rzeczy i procesów realizujących się w konkretnych sytuacjach, w działaniu układów rzeczy i procesów. Zawsze jakoś «działa» coś konkretnie «robi» wywołuje różne skutki i efekty. [...] Jest obecna w tych obszarach rzeczywistości, w których zaznacza się jakaś różnica, przejawia się tam, gdzie następuje konkretne działanie i zmiana. Nie ma jej w niezmiennym trwaniu i stagnacji, chociaż potencjalnie tkwi wszędzie jako forma gotowa do przekazu i oddziaływania. Ma naturę sprawczą i dynamicz- 
ną. Dotyczy tak samo świata fizycznego i przyrodniczego, jak i spraw ludzkich oraz społecznych" (Hetmański, 2013, s. 15). Jak widać informacja, a co za tym idzie - także jej przepływy, są kluczowymi elementami w wielu dziedzinach życia i nauki, a na dodatek są na stałe powiązane z pojęciem zmiany.

Drugim kluczowym elementem dla tematu niniejszego artykułu jest zmiana i transformacja. Obecnie wydaje się, że zmienność i dynamika szczególnie intensywnie występują w naszym życiu, jednak, jak wykazuje antropologia, jest to nieodzowny element naszego cywilizacyjnego bytu: „Istnieje pewne błędne przekonanie, że prehistoria ludzkości była okresem stabilności, a zmiany następowały stopniowo. Wcześni antropologowie, którzy żyli w czasach rewolucji przemysłowej i zawirowań politycznych towarzyszących nadejściu kapitalizmu, kontrastowali własne doświadczenia ze społeczeństwami ludów pierwotnych, przedstawionymi jako żyjące w idyllicznych, niezmiennych rajach. Robert Redfield w swojej książce The primitive word and its transformations (1953) przeciwstawił się temu przekonaniu. Zmiana, czasem radykalna, zawsze była elementem ludzkiego doświadczenia i nie zawsze wywoływały ją klimat i inne zdarzenia przyrodnicze" (Page i Rock, 2014, s. 181). Można odnaleźć wiele źródeł opisujących zagadnienia informacji i jej przepływów, czy zarządzania nią w obecnych czasach i środowisku (chociażby opracowań biznesowych). Jednak wydaje się interesujące pytanie, jak te dwa elementy (zmiana i przepływy informacji) występowały w rozważaniach znanych filozofów i myślicieli na przestrzeni dziejów. Można założyć, że tak istotne i wszechobecne elementy obecnego świata powinny występować również w przeszłości. To z kolei powinno być odzwierciedlone w pracach wybitnych myślicieli ówczesnych czasów. Niniejszy artykuł ma na celu dokonanie takiej analizy i zweryfikowanie tego założenia.

\section{METODY BADAWCZE}

Dla każdego z trzech przedziałów czasowych w dziejach filozofii (starożytność - renesans, nowożytność, współczesność) autor artykułu wybrał kilku (dwóch lub trzech) wybitnych filozofów i myślicieli. Wybrani reprezentanci są powszechnie uznani za godnych reprezentantów swoich epok. W przypadku każdego z nich zostały przedstawione ogólny dorobek i sylwetka, a w twórczości (całościowo lub na konkretnym przykładzie - w zależności od 
dorobku myśliciela) została dokonana analiza, w jaki sposób odnosili się do przepływów informacji w kontekście zmiany i transformacji. Na podstawie wyników tej analizy zostały przedstawione końcowe wnioski. Ograniczono się w niej do siedmiu myślicieli, gdyż większa próbka spowodowałaby jedynie bardzo pobieżny przegląd (przy ograniczeniu objętościowej opracowania), co utrudniłoby analizę zagadnienia. Natomiast mniejsza mogłaby zbyt ograniczyć reprezentacje z poszczególnych epok.

\section{STAROŻYTNOŚĆ - RENESANS}

\section{Sun Tzu}

Około 500 roku przed naszą erą w Państwie Środka działał i tworzył strateg i generał Sun Tzu. Jest on twórcą dzieła, które do dziś znacząco wpływa na wiele sfer życia (biznes, marketing, zarządzanie, a nawet styl życia). Jego przemyślenia zostały zawarte w Sztuce wojny (Tzu, 2014). Dzieło to składa się z czternastu rozdziałów tematycznych poświęconych różnym zagadnieniom dotyczącym sztuki wojennej. Sam autor chciał w swojej książce przekazać odbiorcy (z założenia innym praktykom i teoretykom sztuki wojennej) wiedzę, jak postępować podczas przygotowań do wojny lub też w trakcie jej trwania: „Wojna jest największą sprawą państwa, podstawą życia i śmierci, drogą do przetrwania lub zagłady. Trzeba ją uważnie przeanalizować” (Tzu, 2014, s. 14).

Działania wojenne, zarządzanie armią, pole bitwy, są to obszary z natury swej powiązane ze zmianą i transformacją. Po zapoznaniu się ze Sztuką wojny bez trudu można zauważyć, jak na każdym z etapów swoich rozważań (niezależnie od opisywanej domeny wojennej) Sun Tzu bierze pod uwagę przepływy informacji w środowisku działania. Przykładem mogą być chociażby jedne z pierwszych słów Sun Tzu kierowanych do czytelnika: „A zatem, gdy dokonujesz rzetelnej analizy porównawczej w celu odkrycia prawdziwej natury wojny, zadaj pytania: Który władca jest w zgodzie z Tao? Który generał ma większe umiejętności? Który z nich zdobył przewagę Nieba i Ziemi? Czyje prawa i rozkazy są skuteczniej wykonywane? Czyje siły są większe? Czyi oficerowie i żołnierze są lepiej wyszkoleni? Czyj system nagród i kar jest bardziej klarowny?” (Tzu, 2014, s. 14). Strateg analizuje relacje pomiędzy poszczególnymi elementami środowiska działań wojennych i skutki, jakie niosą przepływy informacji w zmiennym otoczeniu (sytuacja ludności teatru 
wojennego, własnej armii - do poziomu motywacji pojedynczych żołnierzy, armii przeciwnika, logistyki, warunków atmosferycznych i terenowych itd.). Jest to element występujący w takim samym natężeniu przez kolejne rozdziały dzieła chińskiego generała. Warto nadmienić, że techniki manipulacji informacją (szpiedzy, dywersja, informatorzy, dezinformacja) podniesione są do rangi jednych $z$ kluczowych narzędzi w skutecznej sztuce wojennej. Ta domena jest bezpośrednio powiązana z przepływami informacji i ich moderacją w zmianie.

Po analizie dorobku Sun Tzu można wysnuć wniosek, że Sztuka wojny w kompleksowy sposób przedstawia zarządzanie przepływami informacji w procesach transformacji i samej zmianie. Czyni to w kontekście jasno określonego celu - zwycięstwa na wojnie i pokonania wroga.

\section{Arystoteles}

Przejdźmy w rozważaniach do starożytnej Europy. Niewątpliwie jednym z ojców filozofii europejskiej był Arystoteles (384 p.n.e. - 322 p.n.e.), który budował swoją twórczość na dokonaniach wielkich poprzedników - Sokratesa i Platona. Jednak rzeczą wyróżniającą twórczość tego filozofa była kompletność opisu otaczających go elementów rzeczywistości. Władysław Tatarkiewicz w swoim wyjątkowym dziele Historia filozofii ujął to w następujący sposób: „Siła twórcza Arystotelesa nie leżała w dziedzinie najogólniejszych zagadnień, lecz właśnie bardziej szczegółowych; Platon był twórcą zasad, a Arystoteles - rozwiniętych teorii” (Tatarkiewicz, 1983a, s. 107). Filozoficzna doktryna, którą zaproponował Arystoteles, jest spójną mapą rzeczywistości, gdzie informacje swobodnie przepływają pomiędzy jej poszczególnymi obszarami. „Jego obraz świata był złożony, zawierał składniki zarówno idealne, jak materialne, a tak samo złożone było jego pojęcie poznania. System ten - dzieło Arystotelesa - był kompromisem, ale dokonanym na całkowicie oryginalnej podstawie" (Tatarkiewicz, 1983a, s. 120). Prace Arystotelesa zapoczątkowały rozwój wielu dziedzin nauki (logika, biologia, psychologia, poetyka, metafizyka, ekonomia, polityka) (Legowicz i Kryszewski, 2016). W tak szerokiej twórczości można znaleźć z łatwością utwory i elementy poświęcone transformacji i zmianie. Jednak aby to potwierdzić, skupmy się na jednym z utworów greckiego filozofa, pokrewnego tematyce do wcześniej omówione- 
go chińskiego eksperta sztuki wojennej. Mowa o polityce i książce Arystotelesa poświęconej tej tematyce nazwanej właśnie Polityka (Arystoteles, 2016).

Arystoteles, analizując podstawowe potrzeby jednostki, proponuje nowy model państwa. W tym modelu podstawą współistnienia jest rodzina (jako wspólnota dwóch istot). Jednak taka elementarna komórka nie jest samowystarczalna. $Z$ tego powodu łączy się $\mathrm{z}$ innymi rodzinami, potem tworzy gminy, a na końcu tego procesu powstaje państwo (polis). Państwo jest bytem samowystarczalnym, będącym w stanie zapewnić bezpieczeństwo fizyczne i bytowe jej członkom. Bazując nawet na tym skróconym opisie modelu Arystotelesa widać, jak wielka zależność i powiązania informacyjne istnieją w tej strukturze. Dobrym przykładem jest księga piąta Polityki opisująca zarówno przyczyny zmiany ustroju, jak i procesy nią rządzące. Sam Arystoteles przedstawia to następująco: „Przede wszystkim tedy jasną jest rzeczą, że jeżeli znamy przyczyny, które wywołują upadek ustrojów, to znamy też i środki pomagające do ich utrzymania. Bo przeciwieństwo wywołuje zawsze przeciwny skutek, a upadek jest przeciwieństwem trwania" (Arystoteles, 2016, s. 126). W swoim dziele Arystoteles analizuje byt państwa całościowo, uwzględniając całe bogactwo procesów informacyjnych w zmianie i transformacji (opisuje jednostki, ustrój, władców, struktury, sąsiedztwo itd.). Dodatkowo, daje jasne wskazówki, jak zarządzać zarówno informacją, jak i zmianą w tej strukturze.

Po przeglądzie spuścizny twórczości Arystotelesa i bazując na przykładzie Polityki, można potwierdzić, że Arystoteles w swoich naukach uwzględniał przepływy informacji w procesach transformacyjnych.

\section{Niccolo Machiavelli}

Niccolo Machiavelli (1469-1527) uważany jest za prekursora filozofii politycznej. Swoje rozważania zebrał w dziele pt. Książę, która jest uważana za jedno z przełomowych utworów w tej dziedzinie: „Książe narzucił nowy kierunek filozofii politycznej, rozrywając wywodzące się od starożytności powiązanie polityki i etyki” (Burkard i inni, 2003, s. 101). Machiavelli swoją wizję polityki zbudował na założeniu, że głównym motywem działań człowieka są żądze (władzy i posiadania), a najważniejsze jest osiągnięcie celu, i to niezależnie od kosztów czy sposobów działania. Etyka czy też religia nie powinna wpływać na politykę, która stoi ponad nimi. Dobro, zło to pojęcia 
drugorzędne w kontekście władzy, państwa i skuteczności osiągania celów (Mikołejko, 2013). Analizując twórczość, a w szczególności to sławne dzieło renesansowego pisarza i filozofa, z perspektywy przepływów informacji, warto przytoczyć rozważania historyka Czesława Nankego z przedwojennego wydania Księcia: „Machiavelli to nie tylko polityk Odrodzenia i historyk, lecz zarazem psycholog, który poruszając zagadnienia zarówno dzisiaj, jak i w XVI wieku żywotne, sięgnąć potrafił do głębi natury ludzkiej i ponurym światłem oświetlił jedną jej stronę - egoizm, który spostrzegł we wszystkich postaciach historycznych jako stałą ich właściwość. Liczyć się też z nią musi każda realna polityka" (Machiavelli, 2005, s. 21). Machiavelli wprost zaleca władcy (księciu) manipulowanie informacją i zarządzanie strefą komunikacyjną z poddanymi tak, aby osiągać swoje cele (czyli uzyskiwać oczekiwane rezultaty $z$ procesów transformacji i zmian). W tych działaniach etyka i pojęcia dobra są drugorzędne: „Trzeba więc, by miał on umysł zdolny do zwrotu (...) nie powinien porzucać dobrego, gdy można, lecz umieć wejść w zło, gdy trzeba” (Machiavelli, 2005, s. 70). Dodatkowo włoski myśliciel apeluje o jak najszerszą perspektywę działań władcy. Pokazuje zależności pomiędzy poszczególnymi elementami struktury państwowej - władca ze swoją administracją, wojsko, grupy społeczne, otoczenia funkcjonowania państwa (sąsiedzi, sytuacja polityczna w innych krajach itd.). Machiavelli doradza, jak być skutecznym w rządzeniu i to jest głównym celem, któremu są podporządkowane wszystkie inne narzędzia (włącznie z procesami informacyjnymi i zmianami).

Po przeanalizowaniu twórczości autora Księcia można powiedzieć, że nauki Machiavellego mówią o tym, jak zarządzać procesami informacyjnymi w danym środowisku w ujęciu holistycznym. Są one poradnikiem dla praktyków tej dziedziny (co potwierdzają obecne czasy, gdzie Książę jest jedną z klasycznych pozycji w dziedzinie zarządzania).

\section{NowożYTNość}

\section{August Comte}

Kolejnym filozofem i myślicielem (reprezentantem nowożytnej filozofii) jest August Comte (1798-1857). Jest on uważany za ojca filozofii pozytywnej. Przyjrzyjmy się bliżej temu typowi filozofii i poszukajmy w niej elemen- 
tów, na którym skupia się temat niniejszego artykułu. Filozofia pozytywna składa się z pięciu filarów. (1) Zajmowanie się jedynie faktami fizycznymi i rzeczywistością. (2) Rozważanie jedynie rzeczy pożytecznych - aby lepiej wspomagać jakość życia i wspierać ludzkość w rozwoju ku lepszemu. (3) Praca w obszarach, gdzie można uzyskać wiedzę pewną. (4) Unikanie obszarów nieścisłych. (5) Skupienie się na pracy pozytywnej - jeżeli krytykowanie to jedynie konstruktywne (Tatarkiewicz 1983b, s. 18). W doktrynie można odnaleźć odwołania zarówno do transformacji (rozwój ludzi; aspekty utylitaryzmu, które same w sobie świadczą o dynamice - wymagają zmian), jak i przepływów informacji (skupienie na wielu rzeczywistych obszarach; unikanie nieścisłości).

Dodatkowym wkładem Comte’a jest zaproponowana przez niego nowa klasyfikacja nauk i umieszczenie w niej socjologii jako nauki najmniej ogólnej, a zarazem najbardziej złożonej. Dzięki tej propozycji zapoczątkował on proces tworzenia socjologii w kształcie znanym obecnie: „Jednak Comte postulował ją, bo potrzebna była w jego systemie. Musiał ją sam budować. Budując zaś - i to było dużą jego zdobyczą - stwierdził, że można i należy rozszerzyć tezę o istnieniu ogólnych praw z nauk o przyrodzie również na nauki o ludziach" (Tatarkiewicz, 1983b, s. 21). Co jest istotne, z perspektywy rozważań tego opracowania, stworzenie oddzielnej nauki - socjologii - pozwoliło w sposób ustrukturyzowany i zgodny z podejściem naukowym zwiększyć obszar naukowy dla przepływów informacji na społeczność, ludzi, jak i procesy zachodzące w nich samych: „Całe życie intelektualne Comte’a jest upartym dążeniem do uprawomocnienia socjologii. Jego wysiłki w tej materii idą tak daleko, że konstruuje «hierarchię nauk» z socjologią jako «królową nauk» (Turner, 2006, s. 9).

To, co finalnie, potwierdza kontrybucję Augusta Comte'a do analizowania zmiany z perspektywy procesów informacyjnych, jest wszczepianie przez niego do nauk humanistycznych podejścia naukowego (a wręcz mechanistycznego), które dostarczyło narzędzi badawczych do operowania przepływami informacji: „August Comte opracował trzyetapową koncepcję ewolucji społecznej, zaczynając od «teologii» czyli wiary w duchy i bogów, a potem w jednego Boga, przez etap «metafizyki» czyli filozofii abstrakcyjnej, aż po kulminację, czyli «pozytywizm» - naukowe rozumienie świata. Przyjęty przez 
niego cel - praktyka społeczna oparta na nauce - wywarła ogromny wpływ na przyjęcie paradygmatu mechanistycznego w naukach humanistycznych" (Page i Rock, 2014, s. 182).

\section{Max Weber}

Max Weber (1864-1920) jest kolejnym przedstawicielem europejskiej myśli naukowej, który wpłynął w znaczący sposób na postrzeganie i rozumienie procesów transformacji i przepływów informacji. Był on twórcą definicji socjologii jako nauki bazującej na działaniu ludzi: „Socjologia jest nauką (w sensie, jaki nadajemy temu bardzo wieloznacznemu słowu), która dzięki interpretacji dąży do zrozumienia działania społecznego i przez to do przyczynowego wyjaśnienia jego przebiegów i skutków. «Działanie» oznacza ludzkie zachowanie (zewnętrzny czy wewnętrzny czyn, zaniechanie czy znoszenie), jeśli i o ile działający, bądź wielu działających, wiąże z nim pewien subiektywny sens. Natomiast działanie «społeczne» jest takim działaniem, które wedle intencjonalnego sensu działającego lub działających odnosi się do zachowania innych ludzi i jest na nich zorientowane w swoim przebiegu" (Weber, 2002, s. 6). Niemiecki filozof wnioskował o połączenie podejścia jakościowego w badaniach i analizach, używanego szeroko w ówczesnej socjologii, z podejściem ilościowym, używanym w fizyce czy chemii. Idąc za tym postulatem, zaproponował koncepcje typów idealnych. Koncepcja ta polegała na wprowadzeniu modelu idealnego (akceptując jego nierealistyczność) dla badanego typu obiektów i wykorzystaniem go do analizy i porównania obiektów rzeczywistych danego typu. Zgodnie z tą orientacją wprowadził do socjologii typy idealne dla zachowań ludzkich i typów władzy. Przy ich pomocy był w stanie interpretować i przewidywać zachowania jednostek i relacje zachodzące w społeczeństwie (Heerikhuizen, 2015). Taki model społeczeństwa bazuje na przepływach informacji pomiędzy jego poszczególnymi elementami, i to zarówno w perspektywie statycznej (trwania struktury), jak i dynamicznej (zmiany i transformacji).

Kolejnym wątkiem poruszanym w pracach niemieckiego naukowca i powiązanym z tematem niniejszego artykułu są jego badania zarówno nad organizacjami i strukturami hierarchicznymi, jak i samą biurokracją. W swojej pracy badawczej i dziełach Max Weber zdefiniował ten obszar 
i opisał prawa w nim rządzące. Był wielkim zwolennikiem tego typu struktur, widząc w nich naturalny i doskonalszy etap rozwoju struktur społecznych (Turner, 2006, s. 635). To również pokazuje, jak bardzo aspekt informacji był istotny w jego twórczości (podobnie jak dla wspomnianej wcześniej koncepcji typów idealnych).

\section{WSPÓECZESNOŚĆ}

\section{Talcott Parsons}

Pierwszym ze współczesnych myślicieli, którego twórczość zostanie omówiona, jest Talcott Parsons (1902-1979). Uważany jest za jednego z najbardziej wpływowych socjologów XX wieku. „Wprawdzie tylko nieliczni zgadzają się ze wszystkimi aspektami teorii Parsonsa, jednak rzadko się zdarza, by ktokolwiek polemizował z tezą, iż Parsons stał się postacią XX stulecia” (Turner, 2006, s. 32). W latach 30. XX wieku zaproponował on system socjologiczny, którego głównym założeniem i motorem było działanie i który miał służyć do analizowania zachowań społeczeństw. Ta teoria socjologiczna, nazwana „social action theory” i opisana w (Parsons, 1937), wprowadzała ujęcie jednostek przez pryzmat roli społecznej (z ich interesami, normami i wartościami), które działając woluntarystycznie, funkcjonują w danym społeczeństwie. Zdefiniowanie przez Parsonsa pojęcia działania woluntarystycznego i użycia go w systemie pozwoliło na jego urealnienie. Główne założenia dla działania woluntarystycznego to uznanie jednostki jako podmiotu dążącego do określonych celów w swoim środowisku (Turner, 2006, s. 32-38). Jednostki te podlegają ograniczeniom, takim jak: własna biologia, geny, czynniki wynikające ze środowiska. Dodatkowo podmioty (jednostki) sterowane są wartościami i normami. Wspomniane czynniki wpływają na ich działanie (czyli na ich wybór celów i środków). Dzięki temu podejściu Parsons wprowadził do swojego systemu kontekstowość działań jednostek (rozumianych jako role społeczne) zarówno dla czynników zewnętrznych ('środowisko, okoliczności), jak i wewnętrznych (biologia, geny, motywacje itd.) (Mohapatra, 2015).

W swoich dalszych pracach Parsons rozwijał generalną teorię społeczną, w związku z czym pozostawił duży dorobek związany z teorią systemów. Stworzył schemat analityczny nazwany AGIL, opisujący cztery główne funkcje systemu społecznego: adaptację, osiąganie celów, integrację, podtrzymy- 
wanie swojej struktury. Zakładając, że głównym paradygmatem dla systemu społecznego jest jego trwanie, zdefiniował jego budowę (przez definicję czterech różnych typów podsystemów) wraz z relacjami i przepływami energii zachodzącymi między tymi podsystemami. Wprowadził skalowalność całości teorii (podsystemy można dekomponować na kolejne warstwy w głąb zgodnie z przyjętą budową), pozwalającą na analizowanie dowolnie dużego systemu (Parsons, 1951). Parsons w swoich pracach dążył do zbudowania „wielkiej teorii” pozwalającej opisać każdy system. „Analiza Parsonsa oddaje dążenie do ujęcia uniwersum w kategorie systemów, podsystemów, wymogów systemowych, uogólnionych środków i związanych z nimi wymian. Tym samym jego koncepcja zatraca charakter socjologiczny i staje się filozofią lub, w najlepszym razie, wielką wizją metaetyczną" (Turner, 2006, s. 48). Kolejnym elementem związanym z tezą niniejszego artykułu i spuścizną amerykańskiego filozofa jest jego rozbudowana teoria ewolucji społecznej. Parsons, wykorzystując stworzone wcześniej tezy, zaproponował mechanizmy ewolucji oraz zdefiniował stadia rozwojowe społeczeństw (w ujęciu systemowym) (Sztompka, 2005, s. 125-126).

Jak widać w powyżej przedstawionym (bardzo skrótowo) ogromnym dorobku badawczym Talcotta Parsonsa, przepływy informacji oraz transformacja były istotną częścią jego prac, a teorie, które pozostawił, wzbogaciły zrozumienie tego obszaru i wyznaczyły kierunek dla kolejnych badaczy.

\section{Mihaly Csikszentmihalyi}

Kolejnym (a zarazem ostatnim) badaczem poddanym analizie w tym artykule będzie amerykański profesor psychologii o węgierskich korzeniach Mihaly Csikszentmihalyi (urodzony w 1934 roku). Ten naukowiec znaczną część swojej pracy poświęcił człowiekowi i jego wewnętrznym procesom związanym z odczuwaniem „szczęścia” w działaniu. Wyniki swoich kilkudziesięciu lat badań nad tym tematem zawarł w swojej książce Flow: The Psychology of Optimal Experience (która stała się bestsellerem po wydaniu w 1990 roku). Przeanalizujmy, jaki wkład wniosła praca profesora (a w szczególności Teoria przepływu, którą stworzył) zarówno do postrzegania procesów informacyjnych, jak i samej zmiany. Będąc młodym ubogim emigrantem (urodzonym i wychowanym w czasach drugiej wojny świato- 
wej w Europie), Csikszentmihalyi zainspirował się zagadnieniem subiektywnego odczucia szczęścia w działaniu. Zaczął analizować zagadnienie korelacji między pojęciem szczęścia a innymi czynnikami występującymi w życiu człowieka (zamożność, zasoby, rodzina, wiek itd.). Za tym tematem podążyły kolejne dziesiątki lat badań i analiz różnych grup zawodowych i wybitnych jednostek osiągających ten stan (Csikszentmihalyi, 2004). Głównym owocem tych prac jest wspomniana teoria „przepływu” opisująca okoliczności, które muszą zaistnieć w człowieku, zadaniu i jego otoczeniu, aby działać w stanie wyjątkowej efektywności. Sam twórca tej teorii opisuje ten stan jako: „(...) moment kiedy umiejętności wykonawcy są dopasowane do wykonania zadań niezbędnych do osiągnięcia celu, w środowisku, gdzie jasno można określić obecny postęp prac i otrzymywać na bieżąco informację zwrotną o wynikach. Skupienie w tym działaniu jest tak duże, że nie pozostawia miejsca na myśli niezwiązane z zadaniem lub zamartwianie się. Samoświadomość zlewa się ze zdaniem, a poczucie czasu jest zaburzone (czas mija szybciej). Same przeżycie związane $z$ wykonywaniem zadania jest tak duże, że nie potrzeba żadnego innego wynagrodzenia czy końcowego zysku $\mathrm{z}$ wykonania zadania, nawet kiedy działanie jest trudne lub niebezpieczne" (Csikszentmihalyi, 1990, s. 71). Homeostaza osiągnięta w stanie przepływu pomiędzy wszystkimi procesami informacyjnymi zachodzącymi w człowieku jest najefektywniejszym stanem działania zdiagnozowanym naukowo. Z kolei autoteliczność (czyli stan, w którym działanie jest celem samym $\mathrm{w}$ sobie) powiązana $\mathrm{z}$ byciem w „przepływie” jest dowodem, że działanie (zmiana, transformacja) jest jego nierozłącznym elementem. Dzięki ogromnej popularności swoich prac (książki i artykuły) udało się profesorowi rozpowszechnić inny sposób postrzegania człowieka w działaniu i przedefiniować pojęcie „szczęścia” jednostki i jej efektywności. A co najważniejsze (w kontekście tego artykułu), podparte to zostało solidną naukową analizą procesów informacyjnych zachodzących w ludziach.

Można stwierdzić, że dorobek myślicieli przedstawionych we wcześniejszych częściach artykułu dotyczył procesów informacyjnych i transformacji w szerszym kontekście - wojny, państwa, polityki, społeczeństwa czy ogólnie nauki. Wkład profesora Csikszentmihalyia dotyczy elementarnego budulca wspomnianych „struktur” - jednostki ludzkiej w działaniu (zmianie). 


\section{Podsumowanie}

Po przeanalizowaniu twórczości siedmiu filozofów i myślicieli działających $\mathrm{w}$ różnych okresach, kręgach cywilizacyjnych, $\mathrm{z}$ innym dostępem do wiedzy, można stwierdzić, że każdy z nich, budując swoje teorie i modele, nawiązywał do procesów przepływów informacji. Zmiana i transformacja są nierozerwalną częścią świata, dlatego też odwołania do zmienności i przepływów informacji zostały wykazane w dziełach omówionych myślicieli. Warto zwrócić uwagę, że wraz z upływem czasu opis zjawisk podawanych przez myślicieli dotyczący przepływów informacji w zmianie był wzbogacany w coraz to nowsze narzędzia badawcze i coraz bardziej wbudowywał się w metodologię danej dziedziny nauki. W związku z otrzymanymi wynikami oraz zaznaczoną we wstępie niniejszego artykułu wszechobecnością przepływów informacji w naszym życiu warto rozważyć dalsze badania nad tym elementem naszej rzeczywistości i jego wpływem na różne dziedziny nauki i życia, zwłaszcza w epoce szybko rozwijających się mediów elektronicznych.

\section{Literatura}

Arystoteles. (2016). Polityka, L. Piotrowicz (tłum.), Warszawa: Wydawnictwo Naukowe PWN. ISBN 9788301143091.

Burkard, F.P., Kunzmann, P., Wiedmann, F. (2003). Atlas filozofii, Warszawa: Pruszyński i Spółka. ISBN 8371807430.

Csikszentmihalyi, M. (1990). Flow, The Psychology of Optimal Experience, New York: Harper \& Row. ISBN 9780061339202.

Csikszentmihalyi, M. (2004, luty). TED Ideas worth spreading, https://www.ted. com/talks/mihaly_csikszentmihalyi_on_flow?language=pl\#t-678904 [dostęp: 28.02.2017].

Heerikhuizen, B. (2015). Classical Sociological Theory: Max Weber, University of Amsterdam, https://www.coursera.org/learn/classical-sociological-theory [dostęp: 12.08.2016].

Hetmański, M. (2013). Epistemologia informacji, Kraków: Copernicus Center Press. ISBN 9788378860464.

Legowicz, J., Kryszewski, W. (2016), Arystoteles, http://encyklopedia.pwn.pl/haslo/ Arystoteles;3871513.html [dostęp:_31.08.2016].

Machiavelli, N. (2005). Książe (wyd. drugie), K. Radwan (red.), C. Nanke (tłum.), Cieszyn: Drukarnia Wydawnicza. 
Mikołejko, Z. (2013, luty). Niccoo Machiavelli, http://bi.gazeta.pl/im/0/13407/ m13407780.mp3_[23.08.2016].

Mohapatra, S. (2015). Sociology of Talcot Parson, University of Delhi, https://www. youtube.com/watch?v=IrcZtN1nffY [dostęp: 7.09.2016].

Parsons, T. (1937). The Structure of Social Action, http://home.ku.edu.tr/ mbaker/ CSHS503/TalcottParsonsSocialSystem.pdf [dostęp: 7.09.2016].

Parsons, T. (1951). The Social Systems, https://archive.org/details/socialsystem00pars [dostęp: 2.09.2016].

Page, L.J., Rock, D. (2014). Fundamenty coachingu, P. Niedzielski (tłum.), Warszawa: Co\&Me publishing. ISBN 9788393656615.

Sztompka, P. (2005). Socjologia zmian społecznych, Kraków: Znak. ISBN 8324005986.

Tatarkiewicz, W. (1983a). Historia filozofii (tom 1), Warszawa: Państwowe Wydawnictwo Naukowe. ISBN 8301025816.

Tatarkiewicz, W. (1983b). Historia filozofii (tom 3), Warszawa: Państwowe Wydawnictwo Naukowe. ISBN 8301025816.

Turner, J.H. (2008). Struktura teorii socjologicznej, Warszawa: Wydawnictwo Naukowe PWN. ISBN 9788301140724.

Tzu, S. (201). Sztuka wojny (wyd. trzecie), B. Oczko (red.), D. Baklarz (tłum.), Gliwice: Helion. ISBN 9788324668342.

Weber, M. (2002). Gospodarka i społeczeństwo, Warszawa: Państwowe Wydawnictwo Naukowe. ISBN 8301132167. 